\title{
The Implementation Of The Distance Learning Period The Pandemic Of Covid-19 In MAN 1 Labuhanbatu Utara
}

\author{
Nurlia Siregar ${ }^{1)}$, Irham Huspa K. Siregar ${ }^{2)}$, Kurnia Putra*3) \\ 1,2,3) Fakultas Keguruan dan Ilmu Pendidikan, Universitas Islam Labuhan Batu, Rantauprapat \\ *Coresponding Author \\ Email : kurniaputra.mpd@gmail.com
}

\begin{abstract}
This research describes about the implementation of the learning period of covid-19 in MAN 1 Labuhanbatu Utara. The purpose of this thesis, namely: (1) Knowing the implementation of distance learning the covid-19 case studies: in MAN 1 Labuhanbatu Utara; and (2) Determine the factors inhibiting the learning of the covid-19 in MAN 1 Labuhanbatu Utara. Research using qualitative methods. Source of research data include primary sources (the head of the school, the homeroom MAN 1 Labuhanbatu Utara, guardians/parents) and secondary sources in the form of documentation and so on. Data collection techniques with interviews and documentation. Step analyze the data by reducing, presenting, and then conclude the data. The processing of the validity of data using triangulation of sources and methods. The results showed the Implementation of distance learning in MAN 1 Labuhanbatu Utara, namely socialization kaldik curriculum emergency covid-19, held a workshop and socialization to the guardians of the students. Teachers prepare RPPM and RPPH emergency, make the introduction video and teachers of the school environment, whatsapp group for sharing tasks, making the video tutorial and learning activities of learners, voice note to the introduction of the religious, and the sheet checklist for habituation day-to-day in the house. The factors that mengahambat the implementation of the learning of the emergency period of covid-19 in MAN 1 Labuhanbatu Utara, namely from the internal factors of the teacher, external factors, a tool supporting the android mobile phone, and internet quota
\end{abstract}

Keywords: Implementation, Learning The Covid-19

\section{INTRODUCTION}

The current world education center to get a very valuable experience, in the process of education that is centered in a building bernana school, with its social distancing Covid-19 is finally learning process of the switch to be in the homes of students-based internet connection or television channel. This event is a very rare event in the middle of the outbreak of Covid-19, the learning process of the students will at least be accompanied entirely by a parent or guardian is probably the most also are implementing work from home. Here is a momentum appears to the surface, because the parents will meet with the obligation to basically return as the primary educator at once in charge of the process of education of his children.

Previously, for most parents who are preoccupied with the affairs of the work, many of which give authority to the school completely as the foundation of the educational process for 
children. conditions due to Covid-19 this gives the opportunity to the parents to build the closeness as well as directly involved in the learning of children at home. Covid-19 is very impactful for the entire sector in Indonesia, social, economic and even political are all exposed to the impact of the spread of the outbreak of Covid-19, the socially is very noticeable change in Indonesia, ranging from closed all educational institutions, the ban on gatherings in public areas so that the call to worship in the house. The Covid-19 managed to change the behavior of the community, especially the people of Indonesia, in addition to the appeal of the government, the public also has an interest if the pattern of their behavior does not change, some of the behavior patterns of the community that will change during and after the outbreak of Covid-19 is completed, a healthy lifestyle, after penyebarnya Covid-19 a lot of the appeal either from the government or community organizations as well as non-governmental organizations to implement a healthy lifestyle is like wearing a mask when out of the house, frequent hand washing as well as multiply the drink vitamins. On the part of education since there is a directive from the Ministry of Education and Culture to make schools and colleges assign learning at home for two weeks, many high school and college who are not yet ready, so many use social media apps and also other free apps (faizin,et al 2020). The beginning of the implementation, pembelajaranan remotely by the community are considered as a type of alternative education or education class two of the lost prestige from the conventional education which requires the presence of the learners. Along with the development of information technology and rapid communication distance learning held online via the internet.

Distance learning online got a high appreciation of society, there is even considered more prestigious than conventional education, which are less likely to take advantage of advances in technology (Munir. 2009). Since the government to implement social distance to prevent the spread of the outbreak of covid-19, there is a restriction of the meeting with the number of lots included in the world of Education. This has an impact on learning and teaching activity in educational institutions of the original face-to-face in the classroom, to shift into a distance education or distance learning in the network (online) with the online system (Widya Sari, et al. 2020). Start the beginning of the year 2020 drastic changes in the field of education began to experience a revolution. Learning was dominated by learning face-to-face to switch with the learning in the network (online) in all education levels, including college. In order to prevent the transmission of corona virus 2019 (Covid-19), education policy a lot of that was born a circular letter issued Minister of education and culture Number 32020 about the prevention of Covid-19 on the Education unit and the Number 36926/MPK.A/HK/2020 about online learning, educators are expected to bring the process of learning fun for the students (Jeffry Handika et al., 2020).

MAN 1 Labuhanbatu Utara is the school madrasah aliyah islamic based. The educational institution is appropriately used to be a place of research due to the institution of the school is geographically located adjacent to the sub-districts other among the district which has the area of a pandemic that is different, which is located in Kecamatan Kualuh Hulu and District Marbau. With its strategic geographic location, then a lot of the citizens in the region 3 district is to entrust his son and daughter to study aliyah in the school.

Not just because of the geographic location of school who want an interesting but there are some learning strategies in the school is different among the schools within that attract the hearts of the guardians of the students apart from the religious school and has a lot of achievements. In addition, many of the problems that underlay for the research such as, learners in the care of the grandmother or the person who is trusted with the reason parents work became factory workers that indeed the time taken for the job. While the guardian referred to or the trusted person is not literate technology that can hinder the learning process in the school. Based on these problems, the researchers will conduct a research with the title of 
the Implementation of Distance Learning The Pandemic of Covid-19 in MAN 1 Labuhanbatu Utara academic Year 2021/2022

\section{RESEARCH METHODS}

\section{Research Design}

This type of research is field research, using qualitative research methods. Qualitative method is a research that intends to understand the phenomenon of what is experienced by research subjects such as behavior, perception, holistically, and by way of description in the form of words and language in a specific context that naturally and by using a variety of methods of natural (Moeloeng, 2013). Qualitative research is more concerned with how the process of a of a situation to get the desired results. Qualitative research is a strategy of inquiry that emphasizes the search for meaning, understanding, concepts, characteristics, symptom, symbol, and description of a phenomenon, focus and multi-method, it is natural and holistic, quality, using some of the way, and presented in a narrative (Joseph and Muri. 2014).

The place and Time of Research

Classroom action research was conducted at MAN 1 Labuhanbatu Utara, which is located at Jl. Padang Maninjau, Kel. Padang Maninjau, Kec. Aek Kuo, Kab. Labuhanbatu Utara, North Sumatra Province, 21455. Research activities carried out in August 2021.

\section{Population and Sample}

The population is a region consisting of objects or subjects that have certain qualities and characteristics set by researchers to be studied and then ditari conclusion. Can be interpreted also as the overall subject of research, both real objects, then abstract, events or symptoms that is the source of the data and have a particular character and the same (Sugiyono, 2014). The population in this research is all educators, namely the head of school and 8 teachers class and companion in MAN 1 Labuhanbatu Utara. With a sample of 49 opinion of the subject (person) individually or in groups, the results of observations of an object (physical), events or activities, and the results of the testing. The subject of the primary data in this research is data the results of the interviews the researcher with the speaker (teacher, parents, and School principals).

\section{Data Collection Techniques}

1. Observation

Observation is a method of assessment that is often used to measure a process and the action of the individual in an event that is being observed (Nana Sudjana, 2010). In this study, in accordance with the object of the research, the researchers chose participant observation. Participant observation is a technique of observation where the researcher took part in the activities carried out by the investigated object. This observation was made with the observe and take notes directly on the object of research, namely by observing the activities that there are in MAN 1 Labuhanbatu Utara.

\section{Interview}

A live interview is an interview conducted directly between the interviewer (interviewer) or the teacher with the people interviewed (the interviewer) or learners without going through an 
intermediary, while the interview is not a direct means the interviewer or the teacher ask something to the students through the perantaan other people or the media. So, do not meet directly to the source (Zaenal Arifin, 2010). According to Zaenal Arifin (2010) the purpose of the interview is as follows:

a. Obtain the information directly for the purpose of describing a thing or situation and the specific conditions.

b. Complete a scientific investigation.

c. Obtain data that may affect a situation or person specific.

\section{Documentation}

The documentation aims to obtain a description, lighting knowledge, as well as evidence and accurate data about the document. In this documentation the researchers seek or obtain data such as pictures, notes, LESSON plans, and so forth. The Data obtained can serve as supplementary data or supporting the results of this study.

\section{RESULTS AND DISCUSSION}

\section{The implementation of distance learning the pandemic of covid-19 in MAN 1 Labuhanbatu Utara}

Based on the results of observation related to the implementation of learning emergency in MAN 1 Labuhanbatu Utara researchers find some innovation in the implementation of learning that includes:

a. The implementation of distance learning

The implementation of distance learning is different with the implementation of the learning's that where made simpler with regard to comfort and state of the learners at home. The implementation of the learning emergency is also not burdensome guardians of students by using the media that are around the home environment of learners. Plus when these parents of students already actively working outside the home, most likely the tools of technology such as mobile phones and the like minimal owned learners, as the solution could be looking for format methods online which is done at night when there are his parents, is given a fun task for students. The task given by the teachers can be integrated with the daily life of the learners in order to become habituation good for learners.

As for the things supporting the implementation of the learning that is used to facilitate distance learning includes:

1) Making lesson plans weekly

Lesson plans weekly is a plan of activities which are prepared for the learning for one week. Planning weekly activities can be shaped network theme. Network theme contains projects which will be developed into learning activities. Way of preparation RPPM is derived from the program semester (prosem) that contains a sub-theme, KD, of the material, plan the activities. RPPM developed from the activities of the semester, but penyajiaannya more complete and operational. 
2) Making lesson plans daily

The plan of implementation of the daily lessons is the planning of the daily program which will be implemented by teachers on a daily basis or in accordance with the program of the institution. Components of The plan of implementation of the daily lessons, among other things: the themes/sub-themes/sub-themes, the allocation of time, day/date, clearing activities, core activities, and closing activity.

3) Video tutorial teacher

To learning via online distance learning teachers should also consider about the ability of the parents/guardians of students, which is where most of the guardians of the students/parents of students who do not feel able to teach learning her son and daughter even though it was early learning or stage. Therefore each of the activities given to students each day teachers also give a tutorial video or if to recite and memorize the daily prayer, hadith, short letter, and fasholatan teacher gives voicenote which can be played and learned by the students even though the only home study course. And the video tutorials or voicenote teacher in the share through whatsapp group has been formed in accordance with the class and homeroom teacher respectively.

4) whatsapp Group

To facilitate teachers and students in carrying out distance learning, then teachers make whatsapp group in each of the groups with the homeroom teacher and teacher assistant. Whatsapp group used as a means of supporting the achievement of distance learning. In it contains the plan of implementation of the learning in the share guardian grade or teachers, as well as reporting the results of study of students who would later become the cornerstone of the assessment given by the teacher during the learning done remotely.

5) Sheet checklist

During the learning done in a virtual or distance learning, it automatically teachers can't do habituation routine is typically done at the school to train the independence of learners. Then the teacher invites the parents to guide and supervise their children during distance learning for habituation good and can be done at home independently. Such as habituation fold the blanket after waking up in the morning, wash hands before eating, brushing their own teeth, the koran, and so forth and make a sheet checklist to check with parents/ guardians if students have done the activities of habituation that is given to learners.

b. Meeting guardians of students gradually

The success of the implementation of the learning of students a teacher can not walk independently and is not separated from the role of parents/guardians of students. Then from it to the parents or guardians of students are aware of learning learners that can be done anywhere and learning should not always done in the classroom, then held a meeting of the guardians of the students to promote distance learning (distance learning) periodically and remain in compliance with the protocol of the health on 15-18 August 2021 in the school building MAN 1 Labuhanbatu Utara. Teachers also encourage sharing how the procedure of learning that will be implemented at home. In addition, teachers also facilitate the supporting tools of learning 
such as scissors, glue, plasticine, paper folding, pencil, eraser, coloring, and picture books to enrich and simplify the current distance learning is implemented.

c. Making a Video introduction to the teacher and the school environment

In the academic year 2020/2021 this MAN 1 Labuhanbatu Utara get new students received in class XI MIPA 1 approximately 66 students. Due to circumstances that do not allow for implementing learning and The Orientation of the School (MOS) in person or face-to-face, then guru-guru MAN 1 Labuhanbatu Utara introduce yourself as well as the school environment through a video that is uploaded to YouTube.

\section{The factors that hinder the implementation of learning emergency in MAN 1 Labuhanbatu Utara}

Based on the results of observation in MAN 1 Labuhanbatu Utara things into factor inhibiting the learning implementation plan (emergency) include:

\section{a. Internal factors}

In this problem not only students who fret but some teachers also feel restless, because basically the role of the teacher cannot be replaced by technology, because the technology does not have all the competencies possessed by the teachers (basic competence, pedagogic, personality, social, and professional). To it the role of the teacher is very necessary and need to be improved, so as not to be overwritten with the development of technology. With the distance learning it is automotive learning outcomes learners are sent through the whatsapp application, which become an obstacle that not all teachers have a HP that has the internal memory is large, thus causing some disruption system in mobile phones. The solution is given as the head of the school is to how to buy a pendrive and also USB On The Go or often referred to as OTG for quick and easy teacher when moving the learning outcomes of students everywhere.

\section{b. External factors}

1) the parents/guardians of students

Parents/guardians of students learners need to understand that even at home, their children still have to concentrate on the learning process is ongoing. This is where the support and understanding of the parent / guardian of students is needed. From here will also be aware how should parents give education to the children at once to understand what became the task of the teacher. Because of that, parents also need to how to assist their children in learning. Process the task given by teacher to the students turns out to be quite time-consuming, cost, or energy, all the more so for those who are not accustomed to. A day their son and daughter at home in the busy completing the task of the teacher. This process is expected to parents also understand how the real support and their role is very much needed children in the learning process every day. Emergency conditions become like this was expected to sensitize the parents of his role in assisting, guiding, and directing their children in the completion of the learning process. They also want to don't want to get to know more closely the attitude and the character of their child. 
However, the constraint that some guardians of students at MAN 1 Labuhanbatu Utara worked as a factory worker so that the time to implement the learning in the house becomes very little. As a result for the time of deposit of the learning outcomes of the online learners to be there on time, even at night there is any guardians of students new depositing the learning outcomes of your son/daughter to the teacher. So here the role and hours of work of the teacher becomes much because to ensure the acceptance of the learning outcomes of students.

2) Communication Tools (HP)

HP devices to be vital at a time when the implementation of online learning is used as a medium of communication between students and teachers, both in the delivery of material and the submission of tasks to do at home. However, there are still some parents of students who do not have a mobile phone or have only one and take it to work, and there are also cases of parents who have children older than 2 and they also need a phone to do remote learning so that to the sister who most small to be succumbing to do their job after their sister finished studying. For the solution of problems such as this, are discussed at meetings of the socialization of guardians of the students .about the socialization of distance learning (Distance Learning) then the guardian of the pupil which is adjacent to the learners who have no means of communication are willing to help send the task.

3) the Lack of internet quota

Many encountered problems like this in online learning. Moreover, many older people complain of not getting the income due to the affected by covid-19. For the needs of day-to-day course is not enough let alone to buy internet quota. Need to come again in such a situation the solution of this problem, namely during the online payment syahriah or school fees, give a discount of $50 \%$. So for a $50 \%$ can help parents to buy a data package to meet the needs of the online son of his daughter.

\section{CONCLUSION}

From the data obtained in the field, through the data collection techniques of observation, interview, and documentation about the implementation of distance learning the pandemic covid-19 following :

1. 1The implementation of the learning emergency in MAN 1 Labuhanbatu Utara, namely at the start with its virtual meeting with the ministry of religious Kabupaten Labuhanbatu Utara about socialization kaldik curriculum emergency covid-19, then to take the school held a workshop on the preparation of K-13 emergency response led by the supervisory Mother Furhatul Wafiah, S. Ag, M.M. The head of the school MAN 1 Labuhanbatu Utara immediately respond to the issue and held a socialization to the guardians of the students of class XI MIPA 1 and class XI MIPA 2 where guardians of the students of class XI MIPA 1 is new to the teaching and learning process with no 
face-to-face. To support the success of the implementation of distance learning the covid - 19 teacher prepare RPPM and RPPH emergency, make the introduction video and teachers of the school environment, whatsapp group for sharing tasks, making the video tutorial and learning activities of learners, voice note to the introduction of the religious, and the sheet checklist for habituation day-to-day in the house.

2. 2. The factors that mengahambat the implementation of the distance learning period of covid-19 in MAN 1 Labuhanbatu Utara, namely from the internal factors of the teacher, the external factors of the parents/guardians of students, a tool supporting android mobile phone and quotas.

\section{REFERENCES}

Arifin, Zaenal. 2010. Evaluasi Pembelajaran Bandung: PT Remaja Rosdakarya.

Faizin, Ahmad dan David Efendi. 2020. Membaca Korona: Esai-esai Tentang Manusia, Wabah, Dan Dunia. Gresik: Caremedia Communication. hal. 50-52.

Handika, Jeffry dkk. 2020. Pembelajaran Sains Di Era Akselerasi Digital.

Munir. 2009Pembelajaran Jarak Jauh Berbasis Teknologi Informasi Dan Komunikasi. Bandung: Alfabeta CV, h. 8 .

Moleong, Lexy J. 2013. Metode Penelitian Kualitatif. Edisi Revisi. Bandung.

Sugiyono. 201. Metode Penelitian Kuantitatif Kualitatif dan R\&D. Bandung: Alfabeta.

Sudjana, Nana, 2010. Dasar-dasar Proses Belajar. Bandung: Sinar Baru.

Yusuf, Muri. 2014. Metode Penelitian Kuantitatif, Kualitatif \& Gabungan. Jakarta: Kencana.

Widya Sari, Andi Muhammad Rifki, Mila Karmila. 2020. Analisa Kebijakan Pendidikan

Terkait Implementasi Pembelajaran Jarak Jauh Pada Masa Darurat: Jurnal Ilmu

Pendidikan. 